\title{
LEXICAL VERNACULAR IN THE SPEECH OF LITERARY LANGUAGE USERS RESIDING IN PERM REGION
}

\author{
Tamara I. Erofeeva \\ Perm State National Research University, Perm, Russia \\ Svetlana V. Shustova \\ Perm State National Research University, Perm, Russia
}

\begin{abstract}
The article considers the influence of dialectal layer of the languages by means of incorporating vernaculars into the lexical system of the literary language. It is stated that substandard verbs most frequently get the status of colloquial verbs due to their expressive semantic content or to their wider area of usage. The material for the analysis was 24 substandard verbal lexemes recorded in the explanatory and dialectal dictionaries of the Russian language and found in the speech of native speakers of the literary language. Data on the use of these units were obtained from recordings of the speech of residents of Perm and cities of Perm Krai (the total duration of the audio is about 30 hours). The research is based on the description of the semantic and functional-stylistic potential of vernacular vocabulary. The dynamics of stylistic characteristics of a word is described on the basis of the data recorded in lexicographic publications of different years. It is shown that the transition of words from one subsystem of the Russian language to another is a natural and logical process that contributes to the enrichment of the vocabulary of the Russian language. It has been confirmed that vernacular is a transitional space between dialects and literary language.
\end{abstract}

Key words: dialect, literary language, vernacular, lexical vernacular, semantics, functional and stylistic characteristic of the word.

Citation. Erofeeva T.I., Shustova S.V. Lexical Vernacular in the Speech of Literary Language Users Residing in Perm Region. Vestnik Volgogradskogo gosudarstvennogo universiteta. Seriya 2. Yazykoznanie [Science Journal of Volgograd State University. Linguistics], 2020, vol. 19, no. 4, pp. 42-51. (in Russian). DOI: https://doi.org/ 10.15688/jvolsu2.2020.4.4

\section{ЛЕКСИЧЕСКОЕ ПРОСТОРЕЧИЕ В РЕЧИ НОСИТЕЛЕЙ ЛИТЕРАТУРНОГО ЯЗЫКА ПЕРМСКОГО РЕГИОНА}

Тамара Ивановна Ерофеева

Пермский государственный национальный исследовательский университет, г. Пермь, Россия

\section{Светлана Викторовна Шустова}

Пермский государственный национальный исследовательский университет, г. Пермь, Россия

Аннотация. В статье рассматривается проблема перехода диалектных единиц в лексическую систему литературного языка и выявляется роль просторечия в этом процессе. Материалом для анализа послужили 24 глагольные просторечные лексемы, зафиксированные в толковых и диалектных словарях русского языка и встречающиеся в речи носителей литературного языка. Данные об употреблении этих единиц получены на основе изучения записей речи жителей Перми и населенных пунктов Пермского края (общий объем звучания - около 30 часов). Исследование базируется на описании семантического и функционально-стилисти- 
ческого потенциала просторечной лексики. Охарактеризована динамика стилистических параметров слова на основе их фиксации в лексикографических изданиях разных лет. Показано, что перемещение слов из одной подсистемы русского языка в другую представляет собой естественный и закономерный процесс, способствующий обогащению лексических пластов русского языка. Чаще всего статус разговорного получает просторечный глагол, выражающий экспрессивную семантику или имеющий широкую территорию бытования. Подтверждено, что просторечие выступает в качестве переходного пространства между диалектами и литературным языком.

Ключевые слова: диалект, литературный язык, просторечие, лексическое просторечие, семантика, функционально-стилистическая характеристика слова.

Цитирование. Ерофеева Т. И., Шустова С. В. Лексическое просторечие в речи носителей литературного языка Пермского региона // Вестник Волгоградского государственного университета. Серия 2, Языкознание. -2020. - Т. 19, № 4. - С. 42-51. - DOI: https://doi.org/10.15688/jvolsu2.2020.4.4

\section{Введение}

Речь города - сложное структурированное целое, в котором устный литературный язык занимает центральное место. При этом, спроецированный на определенную территорию, он испытывает воздействие диалекта, проявляясь в различных региональных вариантах. Кроме того, существенную роль в разговорной стихии современного города играет просторечие [Гельгардт, 1959; Ерофеева, 2005; Ерофеева, Грузберг, 1989].

Понимая просторечие как особый пласт лексики литературного языка [Капанадзе, 1984; Литературная норма..., 1977], придерживаемся мнения, что просторечие - это форма функционирования языка, противопоставленная другим формам функционирования языка в силу целого ряда особенностей. «Общепризнана роль просторечия как переходной сферы между литературным языком и диалектами» [Коготкова, 1977, с. 61].

В работах Л.И. Баранниковой взаимоотношения литературного языка, диалекта и просторечия рассматриваются с точки зрения их использования в обиходно-бытовой речи в разные исторические периоды [Баранникова, 1970; 1974]. В донациональную эпоху обиходно-бытовое общение обеспечивали диалекты. Молодые литературные языки не обладали еще свойством общенародной коммуникации и не могли оказать существенного влияния на говоры. В эпоху образования национального языка территориальные диалекты вытесняются в сферу деревенской жизни. Как пишет Л.И. Баранникова, «обиходно-бытовая функция в этот период переходит к просторечию, полудиалектам и т. п., под которыми понимают различные оттенки переходного типа речи, занимающего промежуточное положение между литературным языком и диалектами» [Баранникова, 1970, c. 19]. Ученый выделяет следующие признаки просторечия: 1) нелитературность (оно не входит в систему литературного языка); 2) внетерриториальность (оно имеет незначительные региональные отличия); 3) вариантность (оно обладает обилием речевых вариантов на всех уровнях и не имеет строгих норм); 4) однофункциональность (оно обслуживает только бытовую речь). К концу XVIII - середине XIX в. просторечие сблизилось с литературным языком и, как следствие, «олитературилось». Возникла особая разновидность литературного языка - разговорная. По справедливому замечанию Л.И. Баранниковой, «став составным компонентом литературного языка, разговорная речь, однако, не порвала и не могла порвать связи с просторечием и диалектами. Эта двойственность истоков разговорной речи отчетливо проявляется в ее последующем развитии» [Баранникова, 1970, с. 23].

Подтверждение этому находим в «Словаре русского языка», изданном в 1985 г. (далее - МАС). Представляя лексику русского литературного языка 60-70-х гг. ХХ в., составители отражают в МАС просторечный пласт лексики русского языка, обозначая его единицы пометой $n$ рост., «то есть просторечное слово или значение указывает на то, что слово (или значение) из-за грубости содержания или резкости выражаемой оценки стоит на границе литературного языка и употребляется в сниженном стиле, в обиходно-бытовой речи» (МАС, т. 1, с. 9). 
Цель исследования - характеристика просторечия как сферы перехода лексических единиц из диалекта в литературный язык.

\section{Материалы и методы исследования}

Рассмотрение просторечия с точки зрения морфологии позволило выявить, что преобладающую часть составляют глаголы. Материалом послужили 24 просторечных глагола, имеющие в МАС помету прост. Показано, как представлены эти единицы в диалектных и толковых словарях русского языка (см. список словарей) и использованы в живой разговорной речи лиц, владеющих литературным языком (50 человек). Записи проведены в г. Перми, а также в городах, станицах и поселках Пермского края, общая продолжительность звучания - около 30 часов. В наших предыдущих работах на основе этих записей обнаружено воздействие народных говоров на просторечие, что прослеживается на всех уровнях языка, в том числе лексическом [Ерофеева, 1979; Ерофеева Е.В., Ерофеева Т.И., Скитова, 2002; Скитова, 1968].

Изучение языкового материала проведено с применением методов индукции, дедукции, описания, наблюдения, интерпретации, элементов компонентного и стилистического анализа.

Исследование проведено в два этапа: 1) описана семантика 24 просторечных глаголов, отраженная в словарях и речи, и выявлены маркеры просторечия; 2) определены функционально-стилистические свойства просторечных единиц в динамике.

\section{Результаты и обсуждение}

Охарактеризуем отобранные 24 просторечных глагола в семантическом аспекте.

Просторечный глагол БЫ'ЧИ́ТЬСЯ с двумя вариантами ударения имеет значение 'быть угрюмым, хмурым' (MAC). Между тем другие словари фиксируют это слово с разными значениями: 'проявлять упрямство, не слушаться' (Акч.); 'глядеть угрюмо; упрямиться' (Словарь Даля); 'упрямиться' (СРНГ). СРНГ указывает и территорию распространения - новг., костр., нижегор., владим. и др. В пермской городской среде гла- гол встречается в речи и женщин, и мужчин; употребляется инженерами, экономистами, юристами, преподавателями и др.: И не надо на всех бы́ читься (жен., 43 г., воспитатель, Добрянка); Я не пойму, чего он бьічится! (муж., 33 г., экономист, Пермь); Он всё бычится на меня (жен., 26 л., учитель, Соликамск); Хватит бычиться, будь повеселее! (жен., 23 г., воспитатель, Пермь). Глагол в этом значении широко употребляется в говорах. Однако правомернее считать его просторечным (в этом значении), поскольку территория и сфера его функционирования достаточно широки.

Просторечный глагол ВКА́ЛЫВАТЬ имеет значение 'работать с большим напряжением, долго и много' (МАС). Пермские носители литературного языка активно прибегают к этому глаголу в речи: Вкалываешь, вкалываешь, а денег как не было, так и нет (жен., 28 л., секретарь-машинистка, Березники); Он вкальввает с утра до ночи (жен., 20 л., студентка-филолог, Пермь); Да он на работе вкальввает (муж., 20 л., студент-историк, Пермь). В семантике глагола отмечены экспрессивные семы 'долго' и 'много', на базе которых развивается в речи переносное значение 'долго идти пешком': $A$ вы из Чусовой? В прошлом году два раза был. Ой не знаю, пойду ли. Что-то уж много больно пешком вкалывать надо (муж., 31 г., инженер, Пермь).

Глагол ВБ́ГТКНУТЬ в значении 'ткнув, заставить выпасть; выколоть' имеет помету nрост. (МАС) и активно используется в городской литературной речи пермяков: Чmo $\mathrm{mbl}$ такая худенькая? Можно глаз выткнуть (муж., 32 г., хирург, Красновишерск); Ocmoрожно, а то глаз выткнешь (жен., 40 л., медсестра, Кунгур). В диалектных словарях слово не отмечается, поскольку сфера его использования (а возможно, и происхождения) - городская речь.

Глагол ДРЫХИНУТЬ имеет значение 'спать' (МАС), в Словаре Даля определяется как 'спать много, долго, беспробудно'. Экспрессивные семы 'долго', 'много', 'беспробудно' указывают на сферу принадлежности лексической единицы - городское просторечие, поскольку выступают в качестве усилительных элементов. Встречается в городской литературной речи: Я зашла к ним, а они дрыхнут без зазрения совести! А лекции 
идут... (жен., 20 л., студентка-юрист, Пермь). Есть случаи использования слова в художественных текстах: Mbl, ротозеи, дрыхнули ... (Колчанов. Старина Оханская). Принадлежность слова к городскому просторечию подтверждает «Словарь просторечий русских говоров Среднего Приобья» (СПРГСП).

Значение глагола ЖА́МКНУТЬ - 'сдавить, стиснуть; сжать' (МАС). Слово в этом значении известно в городской речи: Мама, дай я тесто жамкну (жен., 20 л., студентка-филолог, Пермь); Жамкни раз-два бельё - и ладно (жен., 60 л., пенсионерка, Пермь). Глагол зафиксирован в художественных текстах: Взял этот лучок, через коленку жамкнул (Зеленин. Великорусские сказки). Этот глагол включен в Словарь Даля. Однако правомернее отнести его к просторечным, поскольку, как отмечается в СРНГ, глагол употребим в вологод. (с 1847 г.), вят., тамб., арх., свердл., а также перм. (1856 г.) говорах - на севере и на Урале.

Глагол ЗА́РИТЬСЯ с пометой прост. имеет значение 'с завистью смотреть на что-л.; страстно желать, стремиться завладеть чем-л.' (MAC) и активно используется в городской речи носителей литературного языка Пермского региона: Очень часто-то не употребляю. Только между собой. В фамильярной форме: ой, не зарься! (жен., 25 л., учитель, Пермь); Зариться - завидовать, восхищаться. Он зарится украсть эту кубылку (муж., 45 л., начальник УГРО, Красновишерск); Он на неё позарился. А чё тут зариться-то? (жен., 31 г., врач, Нытва); $3 a-$ риться - ну заглядываться на что-то. Уставиться, смотреть. У самого нет, вот и уставился (муж., 39 л., инженер, Березники); Зариться на чьё-то добро. В обиходе-то широко распространено (жен., 33 г., врач, Красновишерск).

В Словаре Даля глагол определяется так: 'приходить въ зари, в задор, распаляться, сильно хот \$ть, завидовать чему'. Как видим, в значении есть экспрессивная сема 'сильно'. В МАС также подчеркивается экспрессивный характер глагола, в толковании эксплицируются экспрессивные семы 'с завистью', 'страстно', поскольку фиксируется сильное эмоциональное возбуждение.

В речи женщины, юриста 44 л. из Перми, встретился глагол ЗАХОМУТА́ТЬ в зна- чении 'полностью подчинить себе': Дарья быстро захомутала Фёдора. В этом значении глагол отмечен в СПГ, СРНГ. Тем не менее экспрессивная сема в значении глагола способствовала изменению сферы распространения слова и квалификации его как просторечного в указанном значении.

Диада ЗАЧА́ТЬ - ЗАЧИНА́ТЬ в значении 'начать - начинать' квалифицируется в МАС как просторечная и активно используется в обыденной и художественной речи: Баню ещё тем летом строить зачали (муж., 48 л., бухгалтер, ст-ца Кын); Давай сегодня зачнем, а завтра посмотрим (жен., 47 л., библиотекарь, Кунгур); Главное зачать, a потом дело пойдёт (жен., 23 г., агроном, пос. Куеда); Ну ты зачинай, а я чуть позднее подойду (жен., 29 л., продавец, Пермь); Следует зачинать дело (муж., 49 л., учитель, Кунгур). Лексема представлена в художественных текстах Д.Н. Мамина-Сибиряка, А. Колчанова, А. Бондина, А. Кирпищиковой и др. Просторечные глаголы ЗАЧА́ТЬ - ЗАЧИНА́ТЬ характерны для речи тех горожан, которые не овладели нормами литературной речи. Оба глагола отмечены в СПРГСП.

Глагол КАЗА́ТЬ - 'показывать', устар. и nрост. (МАС). Глагол КАЗА́ТЬ встречается и в речи носителей литературного языка: Чaсто спрашивают: "Какое кино кажут?» (муж., 27 л., учитель, Пермь); Сейчас начнётся передача, а телевизор ничего не кажет. У нас паршиво кажет телевизор (жен., 28 л., учитель, Пермь); Вот сейчас Польшу всё кажут (муж., 40 л., геолог, Красновишерск). Просторечный характер глагола отмечен и в СПРГСП.

Многозначный глагол ЛА́ДИТЬСЯ, по данным МАC, в городской речи представлен литературным, диалектным и просторечным лексико-семантическими вариантами значения. Лит. - 'удаваться, идти успешно': У неё ладится в работе всё, хорошо получается (жен., 35 л., учитель, Пермь); Дело что-то не ладится (муж., 37 л., инженер, Красновишерск). Диал. - 'уславливаться, договариваться': Хватит вам ладиться! (жен., 22 г., студентка-филолог, Чусовой); Ладиться - это значит договорились о чём-то (муж., 40 л., преподаватель, Красновишерск). Прост. - 1. 'намереваться’: Он всё ладится её обнять (муж., 40 л., 
инженер, Частинский р-н). 2. 'изготовляться': Мотор ладится совершенно иначе, чем я предполагал (муж., 34 г., юрист, Красновишерск). 3. 'хорошо продвигаться': Всё вроде теперь ладится (жен., 30 л., воспитатель, Кунгур); Ладится, клеится - успешный резульmam! (муж., экономист, пос. Куеда). Второе и третье значения глагола отмечены в СПРГСП.

Двенадцатое значение глагола НАБИ́Ть, по определению МАС, является просторечным - 'побить, поколотить кого-л.' . Это подтверждает в СПРГСП. В СРНГ у этого глагола первым зафиксировано значение 'избить, поколотить' и отмечены следующие территории распространения - тобол. (с 1911 г.), иркут., бурят., АССР, сиб., вост., казах., свердл., перм. (Мама, он набьёт меня), сев.-двин., онеж., ленингр. Такое употребление глагола в диалектах способствовало его использованию в городском просторечии и в речи носителей литературного языка: Будь осторожна, он какой-то дикий. Может набить тебя! (жен., 28 л., кассир, Чусовой).

Диалектное значение глагола НАКАЗА́ТЬ - 'приказывать, велеть' - отмечено СРНГ на большой территории (начиная с 1820 г.). Это, несомненно, способствовало тому, что уже в БАС и МАС глагол в значении 'дать наказ, велеть, поручить' получает статус $y c$ map. и прост. Как просторечное слово фиксируется в СПРГСП. Городские жители часто используют глагол в этом значении в речи, в том числе и литературной. Например: Накажи ему строго, чтобы ни с кем из незнакомых не разговаривал! (жен., 45 л., воспитатель, Березники); А матери накажите, чтобы регулярно принимала это лекарство (жен., 55 л., врач, Пермь); Я ему наказал, чтобы сюда больше не приходил (муж., 34 г., юрист, Красновишерск); Ты накажи ей привезти продуктов из Перми (жен., 28 л., кассир, Соликамск); Строго-настрого мать накажет это сделать. И не возражай! (жен., 35 л., библиотекарь, Соликамск); Наказала накормить цыплят (муж., 40 л., механизатор, пос. Куеда).

Глагол ОБСКАЗА́ТЬ определяется в МАС следующим образом: 'подробно рассказать, объяснить'. Просторечный глагол частотен в речи носителей литературного языка: Обсказывай всё по порядку, не торопись (жен.,
63 г., учитель, пенсионерка, Кунгур); Tbl, Мария, всё подробно обскажи (жен., 48 л., библиотекарь, ст-ца Кын); Я тебе всё обсказала (жен., 30 л., литсотрудник, Б. Соснова). В значении глагола актуализируется сема 'подробно'.

Глагол ОГОЛОДА́ТЬ. Определяя просторечный характер слова, МАС дает следующее его значение: 'отощать от голода; изголодаться'. Между тем в СПГ глагол фиксируется как принадлежащий пермским говорам. Отмечено слово и в речи носителей литературного языка: Совсем оголодала (жен., 38 л., библиотекарь, Кунгур). СРНГ дает слово в форме ОГОЛОДЕ́ТЬ, первое значение которого - 'сильно проголодаться'. Экспрессивная сема 'сильно' способствует переходу слова из диалектного в просторечное.

В публичной речи отмечен просторечный глагол ОЗОРОВА́ТЬ: Любители природы частенько озоровали на землях подсобного хозяйства (областная газета «Звезда»). Его значение - 'нарушать общепринятые нормы поведения'. Диада ОЗОРОВА́ТЬ ОЗОРНИЧА́ТЬ, разг. характеризуется высокой степенью экспрессии.

Глагол ОКЛЕМА́ТЬСЯ в значении 'выздороветь, оправиться после болезни; прийти в сознание', nрост. (МАC) широко употребителен в речи городских носителей литературного языка в Пермском регионе: Дня два назад из похода пришли, так я только вчера оклемалась (жен., 33 г., учитель, Пермь); Оклематься не успела после больницы - и уже опять болезнь (жен., 42 г., методист, Кунгур); Вот оклемаюсь и выйду на работу (муж., 45 л., мастер, Березники); Еле оклемалась баба Нюра после второго приступа... (муж., 23 г., медбрат, Верещагино); Как оклемаюсь немного, и подумаем, что дальше делать (жен., 37 л., концертмейстер, Пермь); Как она не будет болеть? Немного оклемается - опять раздетая на улииу выбегает (жен., 45 л., учитель, пос. Октябрьский); Я как кровь-то увидела, мне аж дурно стало. В глазах потемнело, еле оклемалась потом (жен., 22 г., учитель, Чернушка). Акч. считает слово диалектным. СРНГ указывает очень широкую территорию использования слова в этом значении. Несомненно, что глагол в этом значении можно (и нужно) квалифицировать как просторечный. 
Значение глагола ОПРОСТА́TЬ - 'освободить от содержимого; опорожнить' (МАС, БАС). Слово фиксируется в Словаре Даля, Рязанском словаре, Акч., СПГ. Широко используется и в городской речи носителей литературного языка; его знают и достаточно часто употребляют в речи все опрошенные: Onростать - опустошить, вblлить всё содержимое из неё. Пойди опростай кастрюльку, она мне нужна (жен., 25 л., учитель, Пермь); Говорю, правда, тоже не очень часто. Tы, мама, уже опростала эту сумку? Давай опростай, она мне нужна (жен., 38 л., учитель, Пермь); Лучше скажу - опростать. Ты мне опростай эту посуду (муж., 31 г., преподаватель, Красновишерск); Опростай корзину, она была занята (муж., 32 г., конструктор, Краснокамск); Oпростать - легче говорить (жен., 36 л., заведующая детсадом, Кунгур); Ведро опростала? Надо по воду идти (муж., 22 г., инженер, Пермь). Слово отмечено в СПРГСП. Широкое распространение данного глагола также способствует его квалификации в этом значении как просторечного.

Глагол ОТВОЗИ́ТЬ определяется в МАС как просторечный в значении 'испачкать, извозить'. Между тем он фиксируется в СРНГ в этом значении на территории вятских (с 1901 г.) и кировских говоров. В акчимском говоре Пермского края отмечен возвратный глагол - ОТВОЗИ́ТЬСЯ, зафиксированный в СРНГ с пометой перм. В городской литературной речи Пермского региона используются оба глагола: И когда ты так платье отвозила? Растёт такой неряхой! (жен., 50 л., бухгалтер, Кунгур); Боже мой, отвозилися как! Не узнать вас! (жен., 42 г., воспитатель, Oca); - А можно отсюда посмотреть? Можно, осторожно, отвозитесь. Ну вот, отвозили с этой и с той стороны (муж., 35 л., художник, Красновишерск). Как видим, в речи отмечены и просторечная, и диалектная единицы.

Глагол ПОГЛЯ́НУ́ТЬСЯ используется в городской речи с двумя вариантами ударения: Свататься ходили, мне невестка поглянулась (жен., 52 г., библиотекарь, ст-ца Кын); [Шутливо] Парень-то мне поглянулся (жен., 32 г., корректор, Б. Соснова); Она мне погля- нулась (муж., 43 г., преподаватель, Кунгур); Поглянулось мне у неё платье. Аккуратно сшито (жен., 45 л., учитель, высш., Соликамск); [Шутливо] Может, ты ему и поглянешься (жен., 46 л., бухгалтер, Кунгур). МАС, определяя просторечный характер глагола (с ударением на Н 'Уи толкуя его значение как 'понравиться, прийтись по вкусу', соотносит с глаголом ПРИГЛЯНУ́ТЬСЯ. Глаголы ПОГЛЯ́НУ́ТЬСЯ, прост. и ПРИГЛЯНУ́ТЬСЯ, разг. характеризуются высокой степенью экспрессии.

У глагола ПОПРОВЕ́ДАТЬ с пометой nрост. МАС фиксирует значение 'проведать'. Это слово активно используется в городской речи Пермского региона: Мальчики, а когда мы с вами пойдём в больнииу Сашу попроведать? (жен., 35 л., учитель, Пермь); Он благородный такой мужчина. Где-то тут был, зашёл попроведать. Я состряпала блинчатые пирожки (жен., 58 л., пенсионерка, Ныроб); «A вы по грибы? Хотите на ту сторону?» - «Угу, хочу попроведать тот бор» (муж., 32 г., конструктор, Красновишерск); Пойду схожу бабушку попроведаю (муж., 60 л., пенсионер, Добрянка). По словообразовательной структуре глагол можно считать диалектным (в Словаре Даля зафиксировано большое количество диалектных глаголов с приставками ПОПРО-). Однако в данном случае многочисленные примеры его использования в городской речи позволяют квалифицировать этот глагол как просторечный.

Просторечный глагол СДЮ́жИТЬ имеет значение 'справляться с кем-, чем-л.; одолеть, вынести что-л.' (МАС). Есть случаи использования глагола в пермской городской речи: Надо во что бы то ни стало сдюжить (муж., 37 л., конструктор, Краснокамск); Он здоровый, он всё вытерпит, сдюжит (муж., 45 л., инженер, Пермь); $\mathrm{Pa}$ ботать в лесу тяжело, но надо сдюжить, вытерпеть (муж., 34 г., юрист, Красновишерск); Много работы, но ничего, сдюжим (муж., 48 л., техник, Краснокамск); Сдюжить. Кстати, ребята это слово уже забывают. Недюжинная натура - объясняешь, откуда это слово произошло. Сильный, могучий (жен., 45 л., учитель, Пермь).

Глагол СЛА́ДИТЬ в значении 'сделать, смастерить' известен в говорах (СПГ, 
СРГСУ - в форме СЛА́ЖИВАТЬ), в просторечии (МАС, СПРГСУ) и в городской литературной речи: Сладили печку за неделю (муж., 42 г., агроном, пос. Куеда); Дом они хороший сладили (муж., 60 л., пенсионер, Березники). Принадлежность этого глагола к нескольким формам общенародного языка (литературный язык, диалекты) позволяет считать глагол просторечным.

В ходе исследования определены семантические функционально-стилистические характеристики 24 просторечных глаголов в динамике. С этой целью у данных глаголов сопоставлены пометы в СТСРЯ (2004) и ТСРРР (2010). Результаты отражены в таблице.

Как видно из таблицы, не все глаголы представлены в словарях, не у всех глаголов фиксируется помета, позволяющая соотнести их с определенной сферой употребления, что в свою очередь позволяет говорить о рас- ширении функционально-стилистического потенциала данных единиц.

\section{Заключение}

Перемещение слов из одной подсистемы в другую - естественный и закономерный процесс, способствующий обогащению лексических пластов русского языка. Просторечие в данном случае выступает переходной сферой между литературным языком и диалектами. Статус разговорного чаще всего получает просторечный глагол, маркируемый экспрессивной семой или имеющий широкую территорию бытования. Устойчиво просторечными остаются те глаголы, которые имеют особую словообразовательную структуру, характерную для диалектного слова. К перспективам исследования мы относим разработку словаря просторечных глаголов Пермского региона.

\section{Семантическая и функционально-стилистическая характеристика слова}

\section{Semantic, functinal and stylistic characteristics of a word}

\begin{tabular}{|l|l|c|c|}
\hline $\begin{array}{c}\text { Просторечные } \\
\text { глаголы (МАС) }\end{array}$ & \multicolumn{1}{|c|}{ Семантические и функционально-стилистические } \\
характеристики & \multicolumn{1}{|c|}{$\begin{array}{c}\text { СТСЯ } \\
(2004)\end{array}$} & $\begin{array}{c}\text { ТСРРР } \\
(2010)\end{array}$ \\
\hline Бычиться & Функцонирование на широкой территории & - & - \\
\hline Вкальввать & Наличие экспрессивной семы & разг.-сниж. & разг. \\
\hline Bыткнуть & Функцинирование в городской речи & - & - \\
\hline Дрыхнуть & Наличие экспрессивной семы & разг.-сниж. & разг. \\
\hline Жамкнуть & Функцонирование на широкой территории & - & - \\
\hline Зариться & Наличие экспрессивной семы & разг.-сниж. & разг. \\
\hline Захомутать & Наличие экспрессивной семы & - & разг. \\
\hline Зачать & Просторечие & - & - \\
\hline Зачинать & Просторечие & - & - \\
\hline Казать & Просторечие & - & - \\
\hline Ладиться & Функционирование в разных формах общенародного языка & разг. & разг. \\
\hline Набить & Функционирование на широкой территории & разг.-сниж. & разг. \\
\hline Наказать & Функционирование на широкой территории & разг. & - \\
\hline Обсказать & Наличие экспрессивной семы & - & разг. \\
\hline Оголодать & Наличие экспрессивной семы & разг.-сниж. & разг. \\
\hline Озоровать & Наличие экспрессивной семы & - & - \\
\hline Оклематься & Функцинирование на широкой территории & разг.-сниж. & - \\
\hline Опростать & Функционирование на широкой территории & нар.-разг. & разг. \\
\hline Отвозить & Просторечное & - & - \\
\hline Отвозиться & Просторечное & - & - \\
\hline Поглянуться & Наличие экспрессивной семы & - & - \\
\hline Попроведать & Словообразовательная структура, функционирование в го- & & - \\
\hline родской речи & разг.-сниж. & - \\
\hline Сладить & Фунционирование на широкой территории & нар.-разг. & - \\
\hline
\end{tabular}

Примечание. Символ «-» означает отсутствие глагола в словаре.

Note. Symbol "-" means the absence of a verb in the dictionary. 


\section{СПИСОК ЛИТЕРАТУРЫ}

Баранникова Л. И., 1970. О социально-исторической обусловленности развития разговорной речи // Русская разговорная речь : сб. науч. тр. / редкол.: О. Б. Сиротинина (пред.) [и др.] Саратов : Изд-во Сарат. ун-та. С. 18-25.

Баранникова Л. И., 1974. Просторечие как особый социальный компонент языка // Язык и общество. Вып. 2 : сб. ст. / пред. редкол.: Л. И. Баранникова. Саратов : Изд-во Сарат. ун-та. С. 3-22.

Гельгардт Р. Р., 1959. О литературном языке в географической проекции // Вопросы языкознания. № 3. С. 95-101.

Ерофеева Е. В., 2005. Вероятностная структура идиомов: социолингвистический аспект : монография. Пермь : Изд-во Перм. ун-та. 320 с.

Ерофеева Е. В., Ерофеева Т. И., Скитова Ф. Л., 2002. Локализмы в литературной речи горожан. 2-е изд. Пермь : Изд-во Перм. ун-та. 107 с.

Ерофеева Т. И., 1979. Локальная окрашенность литературной разговорной речи. Пермь : Изд-во Перм. ун-та. 91 с.

Ерофеева Т. И., Грузберг Л. А., 1989. Еще раз о просторечии // Живое слово в русской речи Прикамья : сб. ст. / [редкол.: Ф. Л. Скитова (гл. ред.) и др.]. Пермь : Изд-во Перм. ун-та. С. 3-10.

Капанадзе Л. А., 1984. Современное городское просторечие и литературный язык // Городское просторечие: проблемы изучения : сб. ст. / отв. ред. Е. А. Земская, Д. Н. Шмелев. М. : Наука. С. 5-12.

Коготкова Т. С., 1977. Роль просторечия в процессах освоения говорами лексики литературного языка // Литературная норма и просторечие : сб. ст. / отв. ред. Л. И. Скворцов. М. : Наука. С. 58-76.

Литературная норма и просторечие : сб. ст., 1977 / отв. ред. Л. И. Скворцов. М. : Наука. 255 с.

Скитова Ф. Л., 1968. К вопросу о территориальном варьировании современного литературного языка // Материалы VIII Зональной конференции кафедр русского языка вузов Урала (Шадринск, 20-23 мая 1968 г.). Шадринск : [б. и.]. С. 14.

\section{ИСТОЧНИКИ И СЛОВАРИ}

Акч. - Словарь говора д. Акчим Красновишерского района Пермской области (Акчимский словарь). В 6 вып. Вып. 1 / гл. ред. Ф. Л. Скитова. Пермь : Изд-во Перм. гос. ун-та, 1984. 398 с.

БАС - Словарь современного русского литературного языка. В 17 т. / [гл. ред.: В. И. Чернышев (гл. ред.) и др.]. М. ; Л. : Изд. и 1-я тип. Изд-ва Акад. наук СССР в Л., 1948-1965. 17 т.

Зеленин. Великорусские сказки - Зеленин Д. К. Великорусские сказки Пермской губернии. М. : Правда, 1991. $121 \mathrm{c}$.

Колчанов. Старина Оханская - Колчанов А. П. Старина Оханская. Повести. Пермь : Кн. изд-во, $1962.248 \mathrm{c}$.

$M A C$ - Словарь русского языка. В 4 т. / под ред. А. П. Евгеньевой. 3-е изд., стер. М. : Рус. яз., 1985-1988. $4 \mathrm{~T}$.

Рязанский словарь - Словарь современного русского народного говора (д. Деулино Рязанского района Рязанской области) / под ред. И. А. Оссовецкого. М. : Наука, 1969. 612 с.

Словарь Даля - Даль В. Толковый словарь живого великорусского языка. В 4 т. М. : Гос. изд-во иностр. и нац. слов., 1965. 4 т.

СПГ- Словарь пермских говоров : в 2 вып / сост.: А. Н. Борисова [и др.]. Пермь : Кн. мир, 2000 2002. Вып. 1. 2000. 608 с. Вып. 2. 2002. 576 с.

СПРГСП-Словарь просторечий русских говоров Среднего Приобья / сост.: О. И. Блинова, В. В. Палагина, С. В. Сыпченко. Томск : Изд-во Том. ун-та, 1977. $183 \mathrm{c}$.

СРГСУ - Словарь русских говоров Среднего Урала. В 7 т. / под ред. А. К. Матвеева. Свердловск : Сред.-Урал. кн. изд-во, 1964-1988. 7 т.

СРНГ-Словарь русских народных говоров. М. ; Л. (СПб.) : Наука, 1965-2018. Вып. 1-50 / гл. ред. Ф. П. Филин (вып. 1-23) ; Ф. П. Сороколетов (вып. 24-42) ; Ф. П. Сороколетов, отв. ред. С. А. Мызников (вып. 43-46); С. А. Мызников (вып. 47-50).

СТСРЯ - Современный толковый словарь русского языка / гл. ред. С. А. Кузнецов. М. : Ридерз Дайджест, 2004. 960 с.

ТСРPP- Толковый словарь русской разговорной речи. Проспект / под ред. Л. П. Крысина. М. : Ин-т рус. яз. им. В.В. Виноградова РАН, 2010. 346 с.

\section{REFERENCES}

Barannikova L.I., 1970. O sotsialno-istoricheskoy obuslovlennosti razvitiya razgovornoy rechi [On the Socio-Historical Conditionality of the Development of Colloquial Speech]. Sirotinina O.B. et al., eds. Russkaya razgovornaya rech: $s$. nauch. tr. [Russian Colloquial Speech. Collection of Scientific Papers]. Saratov, Izd-vo Saratovskogo universiteta, pp. 18-25.

Barannikova L.I., 1974. Prostorechie kak osobyy sotsialnyy komponent yazyka [Vernacular as a Special Social Component of Language]. Yazyk i obshchestvo. Vyp. 2: sb. st. [Language 
and Society. Iss. 2. Collection of Articles]. Saratov, Izd-vo Saratovskogo universiteta, pp. 3-22.

Gelgardt R.R., 1959. O literaturnom yazyke v geograficheskoy proektsii [On the Literary Language in Geographical Projection]. Voprosy yazykoznaniya [Topics in the Study of Language], no. 3, pp. 95-101.

Erofeeva E.V., 2005. Veroyatnostnaya struktura idiomov: sotsiolingvisticheskiy aspekt: monografiya [The Probabilistic Structure of Idioms. Sociolinguistic Aspect. Monograph]. Perm, Izd-vo Permskogo universiteta. 320 p.

Erofeeva E.V., Erofeeva T.I., Skitova F.L., 2002. Lokalizmy $v$ literaturnoy rechi gorozhan [Localisms in the Literary Speech of Citizens]. Perm, Izd-vo Permskogo universiteta. $107 \mathrm{p}$.

Erofeeva T.I., 1979. Lokalnaya okrashennost literaturnoy razgovornoy rechi [Local Coloration of Literary Colloquial Speech]. Perm, Izd-vo Permskogo universiteta. 91 p.

Erofeeva T.I., Gruzberg L.A., 1989. Eshche raz o prostorechii [Once Again About Vernacular]. Skitova F.L. et al., eds. Zhivoe slovo v russkoy rechi Prikamya: sb. st. [Living Word in the Russian Speech of Prikamye. Collection of Articles]. Perm, Izd-vo Permskogo universiteta, pp. 3-10.

Kapanadze L.A., 1984. Sovremennoe gorodskoe prostorechie i literaturnyy yazyk [Modern Urban Vernacular and Literary Language]. Zemskaya E.A., Shmelev D.N., eds. Gorodskoe prostorechie: problemy izucheniya: sb. st. [Urban Vernacular: Problems of Study. Collection of Articles]. Moscow, Nauka Publ., pp. 5-12.

Kogotkova T.S., 1977. Rol prostorechiya v protsessakh osvoeniya govorami leksiki literaturnogo yazyka [The Role of Vernacular in the Processes of Dialects Mastering the Vocabulary of the Literary Language]. Skvortsov L.I., ed. Literaturnaya norma i prostorechie: sb. st. [Literary Norm And Vernacular. Collection of Articles]. Moscow, Nauka Publ., pp. 58-76.

Skvortsov L.I., ed. Literaturnaya norma $i$ prostorechie: sb. st., 1977 [Literary Norm And Vernacular. Collection of Articles]. Moscow, Nauka Publ. 255 p.

Skitova F.L., 1968. K voprosu o territorialnom varirovanii sovremennogo literaturnogo yazyka [On the Issue of Territorial Variation of the Modern Literary Language]. Materialy VIII Zonalnoy konferentsii kafedr russkogo yazyka vuzov Urala (Shadrinsk, 20-23 maya 1968 g.) [Materials of the VIII Zone Conference of the Russian Language Departments of Ural
Universities (Shadrinsk, May 20-23, 1968)].

Shadrinsk, [s. n.], p. 14.

\section{SOURCES AND DICTIONARIES}

Skitova F.L., ed. Slovar govora d. Akchim Krasnovisherskogo rayona Permskoy oblasti (Akchimskiy slovar). V 6 vyp. Vyp. 1 [Dictionary of Dialect of Akchim Village, Krasnovishersky District, Perm Region (Akchim Dictionary). In 6 Iss. Iss. 1]. Perm, Izd-vo Permskogo gosudarstvennogo universiteta, 1984. $398 \mathrm{p}$.

Chernyshev V.I., ed. Slovar sovremennogo russkogo literaturnogo yazyka. V $17 \mathrm{t}$. [Dictionary of Modern Russian Literary Language. In 17 Vols.]. Moscow, Leningrad, Izd-vo i 1-ya tipografiya Izd-va Akademii nauk SSSR v Leningrade, 1948-1965.

Zelenin D.K. Velikorusskie skazki Permskoy gubernii [Great Russian Fairy Tales of the Perm Province]. Moscow, Pravda Publ., 1991. 121 p.

Kolchanov A.P. Starina Okhanskaya. Povesti [Old Okhanskaya. Tales]. Perm, Knizhnoe izdatelstvo, 1962. 248 p.

Evgenyeva A.P., ed. Slovar russkogo yazyka. V 4 t. [Russian Language Dictionary. In 4 Vols.]. Moscow, Russkiy yazyk Publ., 1985-1988.

Ossoveckiy I.A., ed. Slovar sovremennogo russkogo narodnogo govora d. Deulino Ryazanskogo rayona Ryazanskoy oblasti [Dictionary of Contemporary Russian Dialect of the Village of Deulino, Ryazan District, Ryazan Region]. Moscow, Nauka Publ., 1969. 612 p.

Dal V. Tolkovyy slovar zhivogo velikorusskogo yazyka. $V 4 t$. [Explanatory Dictionary of the Living Great Russian Language. In 4 Vols.]. Moscow, Gosudarstvennoe izd-vo inostrannykh i natsionalnykh slovarey, 1965.

Borisova A.N. et al., ed. Slovar permskikh govorov: v 2 vyp. [Dictionary of Perm Dialects. In 2 Iss.]. Perm, Knizhnyy mir Publ., 2000-2002, iss. 1, 2000. 608 p; iss. 2, 2002. 576 p.

Blinova O.I., Palagina V.V., Sypchenko S.V., eds. Slovar prostorechiy russkikh govorov Srednego Priobya [Vernacular Dictionary of Russian Dialects of the Middle Ob Region]. Tomsk, Izd-vo Tomskogo universiteta, 1977. $183 \mathrm{p}$.

Matveev A.K., ed. Slovar russkikh govorov Srednego Urala. $V 7 t$. [Dictionary of Russian Dialects of the Middle Urals. In 7 Vols.]. Sverdlovsk, SredneUralskoe knizhnoe izd-vo, 1964-1988.

Slovar russkikh narodnykh govorov. Vyp. 1-50 [Dictionary of Russian Folk Dialects. Iss. 1-50]. Moscow, Leningrad (Saint Petersburg), Nauka Publ., 1965-2018. 
Т.И. Ерофеева, С.В. Шустова. Лексическое просторечие в речи носителей литературного языка

Kuznetsov S.A., ed. Sovremennyy tolkovyy slovar russkogo yazyka [Modern Explanatory Dictionary of the Russian Language]. Moscow, Riderz Daydzhest, 2004. 960 p.
Krysin L.P., ed. Tolkovyy slovar russkoy razgovornoy rechi. Prospekt [Explanatory Dictionary of Russian Colloquial Speech. Prospect]. Moscow, Institut russkogoyazykaim. V.V.VinogradovaRAN, 2010.346 p.

\section{Information About the Authors}

Tamara I. Erofeeva, Doctor of Sciences (Philology), Professor, Department of Theoretical and Applied Linguistics, Perm State National Research University, Bukireva St, 15, 614990 Perm, Russia, genling.psu@gmail.com,https://orcid.org/0000-0003-0316-4302

Svetlana V. Shustova, Doctor of Sciences (Philology), Professor, Department of Linguistics and Translation, Department of Theoretical and Applied Linguistics, Perm State National Research University, Bukireva St, 15, 614990 Perm, Russia, lanaschust@mail.ru, https://orcid.org/0000-0002-8318-7864

\section{Информация об авторах}

Тамара Ивановна Ерофеева, доктор филологических наук, профессор кафедры теоретического и прикладного языкознания, Пермский государственный национальный исследовательский университет, ул. Букирева, 15, 614990 г. Пермь, Россия, genling.psu@gmail.com, https://orcid.org/0000-0003-0316-4302

Светлана Викторовна Шустова, доктор филологических наук, профессор кафедры лингвистики и перевода, профессор кафедры теоретического и прикладного языкознания, Пермский государственный национальный исследовательский университет, ул. Букирева, 15, 614990 г. Пермь, Россия, lanaschust@mail.com, https://orcid.org/0000-0002-8318-7864 